\title{
Mercury Speciation in the Water Distribution System of Skiathos Island, Greece ${ }^{+}$
}

\author{
Alexandra Spyropoulou ${ }^{1}$, Yannis G. Lazarou ${ }^{2}$ and Chrysi Laspidou 1,* \\ 1 Department of Civil Engineering, University of Thessaly, 38334 Volos, Greece; aespyropoulou@gmail.com \\ 2 Institute of Nanoscience and Nanotechnology, N.C.S.R. Demokritos, 15310 Athens, Greece; \\ y.lazarou@inn.demokritos.gr \\ * Correspondence: laspidou@uth.gr; Tel.: +30-242-107-4147 \\ + Presented at the 3rd EWaS International Conference on "Insights on the Water-Energy-Food Nexus", \\ Lefkada Island, Greece, 27-30 June 2018.
}

Published: 2 August 2018

\begin{abstract}
In recent years, mercury (Hg) concentration that exceeds the Maximum Contaminant Level Standard set by the World Health Organisation for drinking water has been detected in the groundwater of Skiathos Island in Greece. The island single source of urban water is groundwater; as a result, tap water has been characterised as unsafe for drinking and people rely on bottled water for their everyday needs. The origin and speciation of $\mathrm{Hg}$ in the aquifer is investigated with the use of the Pourbaix diagram, while the possible correlation with groundwater salinization due to seawater intrusion is examined.
\end{abstract}

Keywords: Pourbaix diagram; mercury speciation; groundwater salinisation

\section{Introduction}

During the last few decades, there has been a growing interest worldwide in mercury and the mechanisms that govern its concentrations in air, soil and water. In many parts of the world, health authorities are becoming increasingly concerned about the effects of heavy metals on the environment and human health [1]. Mercury is one of the most important heavy metal environmental pollutants because of its volatility and accompanying long-range atmospheric transport, its toxicity and its ability to bioaccumulate in organisms [2,3]. Unlike organic contaminants, metals do not undergo microbial or chemical degradation, persisting in their original quantities after their introduction into the environment. Some of them also accumulate in living organisms, causing various diseases and disorders [4]. Mercury has often been used in the chloralkali process, the wood pulping industry, technical instruments (thermometers, barometers), electrical equipment (batteries), dentistry, paints, and military applications, inevitably leading to soil and groundwater contamination [5].

A serious problem that is raised considers the mercury contamination of aquifers used as sources of potable or irrigation water. The subsurface environment may be contaminated either from the mobilization of $\mathrm{Hg}$ in geological deposits or from anthropogenic sources [6]. Often, high $\mathrm{Hg}$ concentrations in sediments have a natural origin, an example being the Mediterranean Sea, where the basin contains about $65 \%$ of the total world $\mathrm{Hg}$ mineral resources [7,8]. Mercury enters the environment as either ionic divalent mercury $[\mathrm{Hg}(\mathrm{II})]$ or elemental mercury $\left[\mathrm{Hg}^{0}\right]$ subjected to various biotic and abiotic transformations. As the chemical speciation of mercury greatly affects its toxicity and transport, the fate of mercury in the subsurface is critical to groundwater quality and public health. Mercury sulfide (HgS, known as cinnabar and meta-cinnabar), is a major ore mineral, and one of the largest $\mathrm{Hg}$ sinks in contaminated sediments and soils. Dissolution of cinnabar in 
aquatic environments is complex and the process could be conceptually simplified in two steps, (a) ionic dissociation of $\mathrm{HgS}$ to $\mathrm{Hg}^{2+}$ and $\mathrm{S}^{2-}$ in water and (b) chemical transformations of the ionic dissociation products [9]. A variety of environmental factors may enhance or inhibit cinnabar dissolution by affecting the aforementioned chemical transformations, most important being the redox tendency ( $\mathrm{p} \varepsilon$ or $\mathrm{Eh}$ ) of the subsurface local environment, including groundwater, as well as the presence of $\mathrm{Hg}$ binding ligands [10].

Aquifer over exploitation near coastal areas disrupts the hydrostatic equilibria established by hydraulic connections that possibly exist between the water reservoirs and seawater [11]. Hydraulic gradients following intensive withdrawal of freshwater in this type of aquifer can favor salt-water intrusion, which degrades the quality of water. Due to the drinking water standards established by various authorities (EU, USA, Canada), salinity values are required to remain low [12]. In addition, aquifer salinisation is often linked with the presence of $\mathrm{Hg}$, as in Tuscany, Italy and New Jersey, USA $[2,13,14]$.

In New Jersey, potable supply wells were found to yield water in which concentrations of total $\mathrm{Hg}$ (unfiltered samples) exceed the State and US Environmental Protection Agency drinking-water maximum contaminant level of $2 \mu \mathrm{g} / \mathrm{L}$ [14,15]. In Tuscany, specifically in the Orbetello-Mt. Argentario area, routine analyses of several wells in the mid-1990s revealed anomalies in $\mathrm{Hg}$ concentration, far beyond the upper limit for drinking water standards fixed by Italian law $(1 \mu \mathrm{g} / \mathrm{L})$. This was not an isolated case along the southern Tuscany coast, since about $50 \mathrm{~km}$ north, in the Gulf of Follonica, three wells used for drinking water were forced shut in 1995 on account of $\mathrm{Hg}$ contamination. Interestingly, in both cases, contamination was coupled with a steep increase in $\mathrm{Cl}^{-}$ values related to the intrusion of seawater [13]. Furthermore, along the coast of the province of Grosseto in southern Tuscany, the well water of five areas started to present Hg concentrations above the limit for drinkable water in 1998. In this part of Tuscany, mercury occurs both as ore deposit and as clastic material within shallow alluvial sediments. Grassi and Netti [2] also observed a close relationship between $\mathrm{Cl}^{-}$and $\mathrm{Hg}$ in different areas, concluding that higher $\mathrm{Cl}^{-}$contents always correspond to higher $\mathrm{Hg}$ concentrations in water.

Overall, in many studies, concerns have been expressed for the increased salt intrusion into the coastal aquifer in regards to the release of heavy metals, such as $\mathrm{Hg}$, to the drinking water supply [16]. For different reasons, such as groundwater over-exploitation, sea-level rise and increased salt applications for winter deicing in northern watersheds, many areas in the US, Europe, and Canada face the same problem, i.e., the contamination of the water supply with $\mathrm{Hg}[1,2,13-17]$. The causes of such elevated heavy metal concentrations in response to the increased salt concentrations have been attributed to cation exchange, complex formation with $\mathrm{Cl}^{-}$and colloidal dispersion [17]. In this paper, a preliminary study for the speciation of $\mathrm{Hg}$ in the water system of Skiathos Island, Greece is presented. The possible reasons for the observed $\mathrm{Hg}$ contamination are examined and an evaluation of the possible relations to the intrusion of seawater is presented.

\section{Materials and Methods}

The island of Skiathos is one of the most popular Greek Islands; it has 5000 permanent residents, while island population grows rapidly during the summer tourist season lasting 5 to 6 months and peaking in August. The tourism industry is a key sector of the island's economy [18]. The island of Skiathos has a small water distribution network with a total of about 3500 water consumption meters; the water demands present high variability and seasonality, while its network has reportedly some of the highest water leakage in Greece. The island faces serious water supply issues, since potable water comes from groundwater of low quality due to aquifer salinization [19]. The entire island water network is mainly supported by a single drilling in the area of Ftelia, while a second smaller one has recently become operational in Ag. Antonios.

According to the water utility company of Skiathos (DEYASK), which is conducting monthly samplings in the water system for quality testing, $\mathrm{Hg}$ has been detected above the permitted limit. The concentration of $\mathrm{Hg}$ has been measured repeatedly to attain values up to $6 \mu \mathrm{g} / \mathrm{L}$, while the maximum permitted European limit for total $\mathrm{Hg}$ in the drinking water is $1 \mu \mathrm{g} / \mathrm{L}[20,21]$ (appearing 
as a red line in Figure 1). According to data from DEYASK, the increase in Hg concentration shows the same periodicity pattern as the water consumption. Increased pumping seems to lead to increased concentrations of $\mathrm{Hg}$ in the water, with a hysteresis of 1-4 months as seen in Figure 1.

The increase of $\mathrm{Hg}$ concentration in the water system is a cause of concern, particularly from 2008 onwards, without a firmly substantiated explanation. The absence of possible anthropogenic sources of $\mathrm{Hg}$ in the vicinity of Skiathos suggests that the observed $\mathrm{Hg}$ in groundwater comes from natural sources, in particular $\mathrm{Hg}$-rich underground minerals. The decrease in $\mathrm{Hg}$ concentration after February of 2015 that is observed in Figure 1 is artificial since DEYASK started to mix the contaminated water with uncontaminated water from the second supplementary drilling, in order to achieve lower concentrations in the water distribution network [22].

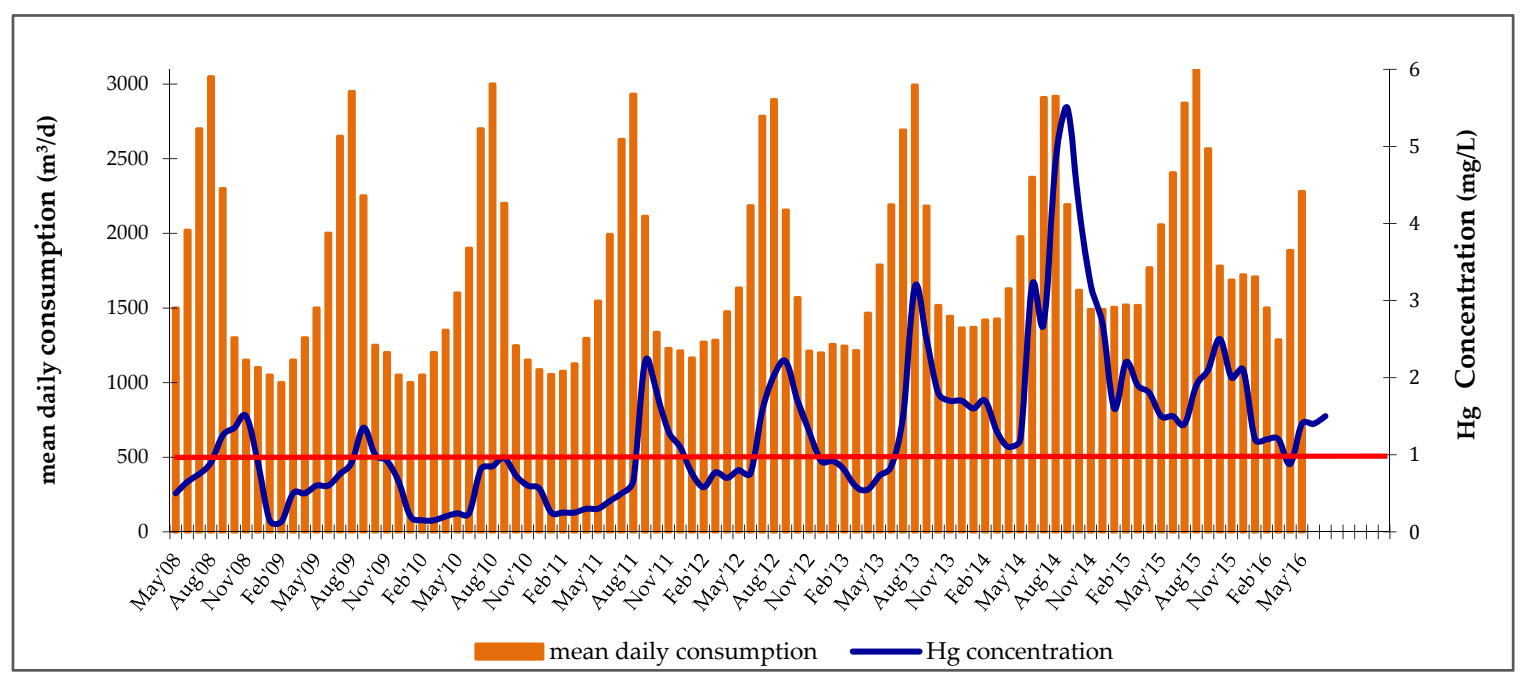

Figure 1. Mean daily water consumption (green bars) and $\mathrm{Hg}$ concentration (blue line) from 2008 to 2016 for the island of Skiathos. The red line is the Maximum Concentration Limit of $\mathrm{Hg}$ for drinking water.

The island's water problem is aggravated by two key factors: the seasonal sharp increase in water consumption due to tourism and the impact of climate change resulting in a temperature rise and rainfall reduction [23,24]. According to Kofinas et al. [25], the increase in water demand is directly related to tourist arrivals in Skiathos, which results in summer water demand being about $170 \%$ higher than that of winter. In order to satisfy the growing needs of the island during the tourist season, groundwater pumping increases, resulting in the influx of sea water that makes the water brackish.

Since mercury is naturally found on the earth's crust mainly in the form of the mineral cinnabar $(\mathrm{HgS})$, it would be reasonable to assume that the same form is present in the subsurface minerals of the Skiathos island, conforming to the relatively high abundance of mercury in the underlying crustal bed of the Mediterranean $[7,8]$. However, since $\mathrm{HgS}$ is practically insoluble in water with an extremely low solubility product $K_{\text {sp }}$ of $1.4 \times 10^{-45}$ [26], we postulate that due to groundwater salinisation, the increase in chloride ion concentration shifts the reaction equilibria towards a higher degree of mercury solubilization by complexation with $\mathrm{Cl}^{-}$anions, resulting in the appearance of $\mathrm{Hg}$ in the water, as emerged by the chemical analyses carried out by DEYASK. By this process, a part of $\mathrm{Hg}$ contained in the minerals escapes to the water and consequently to the main network of the island. A first step for the investigation of the contamination with $\mathrm{Hg}$ in the Skiathos water system is to identify the speciation of $\mathrm{Hg}$ in groundwater.

Under certain conditions, when a solid mineral is exposed to an aqueous solution of inorganic species, chemical reactions may occur on the mineral surface, yielding products which may enter the aqueous phase if sufficiently soluble or remaining on the surface as secondary solid phases. These mineral transformation reactions may be studied by $\mathrm{p} \varepsilon-\mathrm{pH}$ or Eh-pH diagrams (pe and Eh represent the oxidation-reduction tendency of the water medium and $\mathrm{pH}$ represents the activity of the 
hydrogen ion $\mathrm{H}^{+}$), also known as Pourbaix or stability diagrams. Since kinetic bottlenecks are neglected by the assumption of sufficient time available for the reactions completion, these diagrams have been proven to be very useful in geochemistry [27], and are collected in the Pourbaix Atlas $[28,29]$.

In general, a Pourbaix diagram is a kind of phase diagram that shows the stability boundaries for an interaction system consisting of several compounds of a chemical element in water within a range of redox conditions and $\mathrm{pH}$. The diagrams are divided into areas, each of which represents a locally predominant species. A pe-pH diagram can describe not only the effects of potential and $\mathrm{pH}$ but also of chemical complexation, temperature and pressure. By convention, $\mathrm{p} \varepsilon-\mathrm{pH}$ diagrams always show the thermodynamically stable area of water with different marked lines [30] (Figure 2). An aqueous solution phase is always present in such a system. At a given $\mathrm{pH}$ and $\mathrm{p} \varepsilon$, the stability of a particular chemical form of an element may be immediately judged by the knowledge of the $\mathrm{pH}$ and the redox intensity of the solution $(\mathrm{p} \varepsilon)$, and thus, the most likely chemical form of the element at the specified conditions can be determined [31,32].

In the present study, the Pourbaix diagrams were applied for the identification of dissolved $\mathrm{Hg}$ in the water system of Skiathos, using available data from DEYASK. For the construction of Pourbaix diagrams, the values of $\mathrm{pH}$ and $\mathrm{p} \varepsilon$ are necessary. However, a direct measurement of the redox conditions of groundwater is difficult to perform. It is therefore generally preferable to evaluate it through the use of redox couples [33]. Considering the redox couples of $\frac{\mathrm{NO}_{3}^{-}}{\mathrm{NO}_{2}^{-}}$and $\frac{\mathrm{NO}_{3}^{-}}{\mathrm{NH}_{4}^{+\prime}}$ whereas the concentrations of nitrogen species have been measured analytically in Skiathos, Equations (1) and (2) are obtained which enable an estimation to be made for the redox intensity of the groundwater.

$$
\begin{gathered}
\mathrm{p} \varepsilon_{1}=\frac{1}{2} \log _{10}\left(\mathrm{~K}_{1}\right)-\mathrm{pH}+\frac{1}{2} \log _{10}\left(\frac{\left[\mathrm{NO}_{3}^{-}\right]}{\left[\mathrm{NO}_{2}^{-}\right]}\right) \\
\mathrm{p} \varepsilon_{2}=\frac{1}{8} \log _{10}\left(\mathrm{~K}_{2}\right)-\frac{10}{8} \mathrm{pH}+\frac{1}{8} \log _{10}\left(\frac{\left[\mathrm{NO}_{3}^{-}\right]}{\left[\mathrm{NH}_{4}^{+}\right]}\right)
\end{gathered}
$$

The values $\mathrm{p} \varepsilon_{1}^{0}=\left(\frac{1}{2}\right) \log _{10}\left(\mathrm{~K}_{1}\right)$ and $\mathrm{p} \varepsilon_{2}^{0}=\left(\frac{1}{8}\right) \log _{10}\left(\mathrm{~K}_{2}\right)$ are known from literature to be 14.5 and 14.90, respectively [34], where $K_{1}$ and $K_{2}$ are the equilibrium constants of the reduction half-reactions. The value of the dimensionless quantity $p \varepsilon$ represents an indicator of the redox condition of the subsoil from which the water is pumped.

Grassi and Netti [2] identify the source of $\mathrm{Hg}$ in well waters using its Pourbaix diagram in the Mediterranean area of Grosseto, Tuscany during the summer of 1998. The areas of Grosseto and Skiathos have many similarities, both located near the coast with groundwater salinisation due to seawater intrusion and a comparable seasonal variability due to tourism; furthermore, cinnabar may exist in both areas. Considering that the $\mathrm{pH}$ of groundwater was found to vary within the range 6.3 to 8.0, it was concluded that $\mathrm{HgS}$ could be stable only in significantly reducing conditions. On the other hand, $\mathrm{Hg}^{0}$ has a wider stability field, remaining stable under both reducing and oxidizing conditions (Figure 2). Due to the similarities of Grosseto and Skiathos, the former Pourbaix diagram [2] is used here for the identification of dissolved $\mathrm{Hg}$ speciation. 


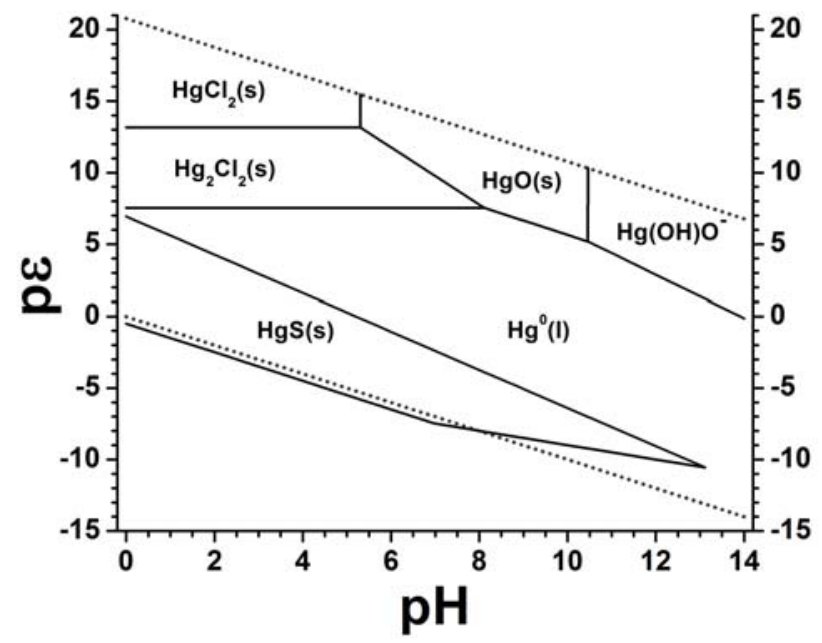

Figure 2. Pourbaix diagram for $\mathrm{Hg}$ solid phases, in contact with a water solution with $\mathrm{Cl}^{-}$and $\mathrm{SO}_{4}^{2-}$ concentrations of $10^{-3} \mathrm{~mol} / \mathrm{kg}$ at 1 bar total pressure.

\section{Results and Discussion}

By using the DEYASK monthly data for $\mathrm{pH}$ and the concentrations of $\mathrm{NO}_{3}^{-}, \mathrm{NO}_{2}^{-}, \mathrm{NO}_{4}^{+}$, the values of $\mathrm{p} \varepsilon_{1}, \mathrm{p} \varepsilon_{2}$ were calculated by equations 1 and 2 on a monthly basis; they were then averaged on a yearly basis from 2003 to 2017, and they are presented in Table 1 .

Table 1. Yearly Average of $\mathrm{p} \varepsilon_{1}, \mathrm{p} \varepsilon_{2}$ from 2003-2017 based on $\mathrm{pH}$ values for Skiathos water system.

\begin{tabular}{cccc}
\hline Year & $\mathbf{p H}$ & Yearly Average $\mathbf{p} \boldsymbol{\varepsilon}_{\mathbf{1}}$ & Yearly Average $\mathbf{p} \varepsilon_{\mathbf{2}}$ \\
\hline 2003 & 7.55 & 6.93 & 5.31 \\
2004 & 7.73 & 7.08 & 4.99 \\
2005 & 7.64 & 7.23 & 5.28 \\
2006 & 7.90 & 6.89 & 5.04 \\
2007 & 8.29 & 6.11 & 4.64 \\
2008 & 7.65 & 7.64 & 5.45 \\
2009 & 8.08 & 7.32 & 4.93 \\
2010 & 8.04 & 7.25 & 4.93 \\
2011 & 7.96 & 7.39 & 5.02 \\
2012 & 8.02 & 7.24 & 4.92 \\
2013 & 7.94 & 7.38 & 5.06 \\
2014 & 8.33 & 6.83 & 4.53 \\
2015 & 8.07 & 7.18 & 4.87 \\
2016 & 8.05 & 7.29 & 4.87 \\
2017 & 7.44 & 7.58 & 5.54 \\
\hline
\end{tabular}

Considering the Pourbaix diagram shown in Figure 2 and the Skiathos average $\mathrm{pH}$ value range (7.44 to 8.33), the resultant values of $p \varepsilon_{1}$ span the range 6.11 to 7.64 (Table 1), whereas the values of $\mathrm{p} \varepsilon_{2}$ are even lower in the range $4.53-5.54$ (Table 1 ). Both indicators suggest that $\mathrm{Hg}$ is predominantly in the form of elemental (metallic) $\mathrm{Hg}^{0}$ and possibly small amounts of solid $\mathrm{Hg}_{2} \mathrm{Cl}_{2}$ (calomel). Compared with the results of Grassi and Netti [2], it appears that the underground environment, from which water in Skiathos is pumped, is less oxidizing. According to data for the period 20032017, the approximate average chloride ion concentration in the water was $800 \mathrm{mg} / \mathrm{L}$ while that for the sulphate anions was $90 \mathrm{mg} / \mathrm{L}$.

In the Pourbaix diagram constructed by Grassi and Netti [2], it was assumed that $\mathrm{Cl}^{-}$and $\mathrm{SO}_{4}^{-2}$ concentrations are $10^{-3} \mathrm{M}$, which is not fully applicable in the case of Skiathos, where $\mathrm{Cl}^{-}$ concentration was measured to be 20 times higher $(\sim 0.023 \mathrm{M})$. The higher $\mathrm{Cl}^{-}$content of the Skiathos 
groundwater is expected to result in the presence of chlorine-containing $\mathrm{Hg}$ species in the form of water-soluble $\mathrm{HgCl}_{2}$ and $\mathrm{HgCl}_{\mathrm{x}}^{2-\mathrm{x}}$ complexes.

The solubility of metallic $\mathrm{Hg}$ in water is $45 \mu \mathrm{g} / \mathrm{L}$ [33], which corresponds to a concentration of $2.24 \times 10^{-7} \mathrm{M}$ at a temperature of $20^{\circ} \mathrm{C}$. The solubility of $\mathrm{Hg}_{2} \mathrm{Cl}_{2}$ in pure water is determined by the solubility product of $\mathrm{K}_{\mathrm{sp}, \mathrm{Hg}_{2} \mathrm{Cl}_{2}}=\left[\mathrm{Hg}_{2}^{2+}\right]\left[\mathrm{Cl}^{-}\right]^{2}=1.43 \times 10^{-18}$ at $20^{\circ} \mathrm{C}$, therefore the concentration of a saturated solution of $\mathrm{Hg}_{2} \mathrm{Cl}_{2}$ is $8 \times 10^{-6} \mathrm{M}$, which corresponds to $3.8 \times 10^{-6} \mathrm{mg} / \mathrm{L} \mathrm{Hg}_{2} \mathrm{Cl}_{2}$ or $7.7 \mathrm{mg} / \mathrm{L} \mathrm{Hg}$. Considering the relatively high average concentration of $\mathrm{Cl}^{-}$of approximately $0.023 \mathrm{M}$ in water and its "common-ion effect" on the solubility product, the solubility of $\mathrm{Hg}_{2} \mathrm{Cl}_{2}$ decreases dramatically, with a final value of $\left[\mathrm{Hg}_{2}^{2+}\right]=2.7 \times 10^{-15} \mathrm{M}$ corresponding to $2 \mathrm{pg} / \mathrm{L} \mathrm{Hg}$. This approach suggests that $\mathrm{Hg}$ at such $\mathrm{Cl}^{-}$concentrations is not expected to be found as a dilute solution of calomel $\left(\mathrm{Hg}_{2} \mathrm{Cl}_{2}\right)$.

Consequently, a first estimate of the speciation of dissolved $\mathrm{Hg}$ in Skiathos water system is the presence of mostly metallic $\mathrm{Hg}$, followed by traces of $\mathrm{Hg}_{2} \mathrm{Cl}_{2}$ and chlorine-containing complexes of $\mathrm{Hg}$ (II) without being able to exclude organic forms, such as methylmercury $\left(\mathrm{CH}_{3} \mathrm{Hg}^{+}\right)$. Moreover, concentrations in the order of $1.5 \mu \mathrm{g} / \mathrm{L}$ for the total $\mathrm{Hg}$ measured in Skiathos groundwater are consistent with mercury being predominantly in the form of dissolved metal $\left(\mathrm{Hg}^{0}\right)$ whose water solubility is appreciably higher $(45 \mu \mathrm{g} / \mathrm{L})$.

\section{Conclusions}

The water system in Skiathos has been impacted by high $\mathrm{Hg}$ concentrations in the last two decades, rendering water in the island unsafe to be consumed. The island faces water scarcity problems especially during the summer when the number of island residents is rapidly increasing due to tourism. In the study area, the presence of $\mathrm{Hg}$ is due to natural causes since the mineral $\mathrm{HgS}$ most likely exists in the bedrock of Skiathos. However, concentrations of $\mathrm{Hg}$ exceeding the Maximum Concentration Level Standard are being observed only since 2003.

A preliminary investigation of the $\mathrm{Hg}$ speciation in the water system of Skiathos is presented in this article, by utilizing the Pourbaix diagram for $\mathrm{Hg}$ as constructed by Grassi and Netti [2] and the concentrations of nitrogen species $\left(\mathrm{NO}_{3}^{-}, \mathrm{NO}_{2}^{-}\right.$and $\left.\mathrm{NH}_{4}^{+}\right)$for the estimation of the redox indicator $(\mathrm{p} \varepsilon)$ of groundwater. The latter suggests that metallic $\mathrm{Hg}$ is the dominant form of mercury present in the groundwater of Skiathos. A comparison of the pe values between the two case studies (Skiathos and Grosseto, Tuscany) suggests that in Skiathos the subsurface environment appears to possess a lower oxidative tendency, resulting in lower pe values in the Pourbaix diagram.

In coastal areas, aquifer overexploitation due to increased summer demands leads to groundwater salinisation. In turn, high concentrations of $\mathrm{Cl}^{-}$appear to correlate with the presence of $\mathrm{Hg}$ in Skiathos, which is in agreement with other relevant studies on different study areas [2,13-15]. Thus, it appears that the role of increased $\mathrm{Cl}^{-}$concentration in the aquifer is directly linked to the mobilization of $\mathrm{Hg}$. These preliminary results warrant further investigation and must be supported with a monitoring regime and relevant data, in order to reach conclusive results about the speciation of $\mathrm{Hg}$ and finally, to develop a strategic plan for its mitigation.

Author Contributions: Y.L. contributed in the development of the methodology. A.S. wrote the paper with input from Y.L. and C.L. Both C.L. and Y.L. reviewed the paper.

Acknowledgments: Funding for this research is provided by the Stavros Niarchos Foundation, as part of the Post-Doctoral Fellowship Program. The authors wish to acknowledge the General Director of DEYASK, Ioannis Sarris, for providing data and access to the site and for his flawless collaboration with the authors.

\section{References}

1. Kozyatnyk: I.; Lövgren, L.; Haglund, P. On the leaching of mercury by brackish seawater from permeable barriers materials and soil. J. Environ. Chem. Eng. 2015, 3, 1200-1206, doi:10.1016/j.jece.2015.04.017.

2. Grassi, S.; Netti, R. Sea water intrusion and mercury pollution of some coastal aquifers in the province of Grosseto (Southern Tuscany-Italy). J. Hydrol. 2000, 237, 198-211, doi:10.1016/S0022-1694(00)00307-3. 
3. Nriagu, J.O. A global assessment of natural sources of atmospheric trace metals. Nature 1989, 338, 47, doi:10.1038/338047a0.

4. King, J.K.; Harmon, S.M.; Fu, T.T.; Gladden, J.B. Mercury removal, methylmercury formation, and sulfatereducing bacteria profiles in wetland mesocosms. Chemosphere 2002, 46, 859-870, doi:10.1016/S00456535(01)00135-7.

5. Bolan, N.; Kunhikrishnan, A.; Thangarajan, R.; Kumpiene, J.; Park, J.; Makino, T.; Kirkham, M.B.; Scheckel, K. Remediation of heavy metal(loid)s contaminated soils-To mobilize or to immobilize? J. Hazard. Mater. 2014, 266, 141-166, doi:10.1016/j.jhazmat.2013.12.018.

6. Wiatrowski, H.A.; Paula, M.W.; Barkay, T. Novel reduction of mercury (II) by mercury-sensitive dissimilatory metal reducing bacteria. Environ. Sci. Tech. 2006, 40, 6690-6696, doi:10.1021/es061046g.

7. Aston, S.R.; Fowler, S.W. Mercury in the open Mediterranean: Evidence of contamination? Sci. Total Environ. 1985, 43, 13-26, doi:10.1016/0048-9697(85)90028-2.

8. Buffoni, G.M.; Bernhard, M.; Renzoni, A. Mercury in the Mediterranean tuna. Why is their level higher than in Atlantic tuna? A model. Thalass. Jugosl. 1982, 18, 231-243.

9. Kozin, L.F.; Hansen, S.C. Chemical Properties of Mercury. In Mercury Handbook: Chemistry, Applications and Environmental Impact; Royal Society of Chemistry: Cambridge, UK, 2013; pp. 81-127.

10. Benoit, J.M.; Gilmour, C.C.; Mason, R.P.; Heyes, A. Sulfide controls on mercury speciation and bioavailability to methylating bacteria in sediment pore waters. Environ. Sci. Tech. 1999, 33, 951-957, doi:10.1021/es9808200.

11. Jiang, P.; Yanbin, L.; Guaugliang, L.; Yang, G.; Lagos, L.; Yongguang, Y.; Gu, B.; Jiang, G.; Cai, Y. Evaluating the role of re-adsorption of dissolved $\mathrm{Hg}^{2+}$ during cinnabar dissolution using isotope tracer technique. J. Hazard. Mater. 2016, 317, 466-447, doi:10.1016/j.jhazmat.2016.05.084.

12. Van Dam, J.C. Salt water intrusion analysis research needs and opportunities. In Proceedings of the 14th Salt Water Intrusion Meeting, Uppsala, Sweden, 16-21 June 1996.

13. WHO. Guidelines for Drinking-Water Quality, Vol. 1 Recommendations; World Health Organisation: Geneva, Sweden, 1993.

14. Protano, G.F.; Riccobono, F.; Sabatini. G. Does salt water intrusion constitute a mercury contamination risk for coastal fresh water aquifers? Environ. Pollut. 2000, 110, 451-458, doi:10.1016/S0269-7491(99)00317-6.

15. Barringer, J.L.; Szabo, Z.; Reilly, P.A.; Riskin, M.L. Variable contributions of mercury from groundwater to a first-order urban coastal plain stream in New Jersey, USA. Water Air Soil Pollut. 2013, 224, 1475, doi:10.1007/s11270-013-1475-7.

16. Barringer, J.L.; Szabo, Z. Overview of investigations into mercury in ground water, soils, and septage, New Jersey Coastal Plain. Water Air Soil Pollut. 2006, 175, 193-221, doi:10.1007/s11270-006-9130-1.

17. Sun, H.; Alexander, J.; Gove, B.; Koch, M. Mobilization of arsenic, lead, and mercury under conditions of sea water intrusion and road deicing salt application. J. Contam. Hydrol. 2015, 180, 12-24, doi:10.1016/j.jconhyd.2015.07.002.

18. Nelson, S.S.; Yonge, D.R.; Barber, M.E. Effects of road salts on heavy metal mobility in two eastern Washington soils. J. Environ. Eng. 2009, 135, 505-510.

19. Mellios, N.; Kofinas, D.; Papageorgiou, E.; Laspidou, C. A multivariate analysis of the daily water demand of Skiathos Island, Greece, implementing the artificial neuro-fuzzy inference system (anfis). In Proceedings of the 36th IAHR World Congress, The Hague, The Netherlands, 28 June-3 July 2015.

20. Kofinas, D.; Mellios, N.; Papageorgiou, E.; Laspidou, C. Urban water demand forecasting for the island of Skiathos. Proc. Eng. 2014, 89, 1023-1030, doi:10.1016/j.proeng.2014.11.220.

21. WHO. Guidelines for Drinking-Water Quality, 3rd ed.; World Health Organization: Geneva, Switzerland, 2004. Available online: http://www.who.int/water_sanitation_health/dwq/GDWQ2004web.pdf (accessed on 22 January 2018).

22. WHO Mercury and Health. Fact Sheet No. 361. 2012. Available online: http://www.who.int/medicentre/ factsheets/fs361/en/index.html (accessed on: January 22, 2018).

23. Director of DEYASK, Ioannis Sarris, Skiathos Island, Greece. Personal communication, 2017.

24. Solomon, S.; Qin, D.; Manning, M.; Chen, Z.; Marquis, M.; Averyt, K.B.; Tignor, M.; Miller, H.L. Working Group I: The Physical Science Basis. Chapter 5: Observations: Oceanic Climate Change and Sea Level. Contribution of Working Group I to Fourth Assessment Report of the Intergovernmental Panel on Climate Change; IPCC AR4; Cambridge University Press: Cambridge, UK; New York, NY, USA, 2007; p. 996. 
25. Giorgi, F.; Piero, L. Climate change projections for the Mediterranean region. Glob. Planet. Chang. 2008, 63, 90-104, doi:10.1016/j.gloplacha.2007.09.005.

26. Kofinas, D.; Papageorgiou; E.; Laspidou, C.; Mellios, N.; Kokkinos, K. Daily multivariate forecasting of water demand in a touristic island with the use of artificial neural network and adaptive neuro-fuzzy inference system. In Cyber-Physical Systems for Smart Water Networks (CySWater); International Workshop on IEEE: Piscataway Township, NJ, USA, 2016.

27. Brookins, D.G. Eh-pH Diagrams for Geochemistry; Springer Science \& Business Media: Berlin/Heidelberg, Germany, 2012.

28. Pourbaix, M. Atlas of Electrochemical Equilibria in Aqueous Solution, 1st ed.; Pergamon Press: Bristol, UK, 1966.

29. Garrels, R.M.; Christ, C.L. Eh-pH. Chapter 7: In Solutions, Minerals, and Equilibria; Freeman; Cooper and Company: New York, NY, USA, 1975; pp. 172-277.

30. Huang, H.H. The Eh-pH diagram and its advances. Metals 2016, 6, 23.

31. Thompson, W.T.; Kaye, M.H.; Bale. C.W.; Pelton, A.D. Pourbaix diagrams for multielement systems. In Uhlig's Corrosion Handbook, 3rd ed.; The Electrochemical Society and Jon Wiley and Sons: Hoboken, NJ, USA, 2011.

32. Verink, E.D. Simplified procedure for constructing Pourbaix diagrams. In Uhlig's Corrosion Handbook, 3rd ed.; The Electrochemical Society and Jon Wiley \& Sons: Hoboken, NJ, USA, 2011.

33. Stumm, W.; Morgan, J.J. An Introduction Emphasizing Chemical Equilibria in Natural Water. In Aquatic Chemistry, 2nd ed.; Wiley: New York, NY, USA, 1981; p. 780.

34. Stumm, W.; Morgan, J.J. Oxidation and reduction; equilibria and microbial mediation. In Aquatic Chemistry: Chemical Equilibria and Rates in Natural Waters, 3rd ed.; John Wiley \& Sons: New York, NY, USA, 2012; p. 126.

(C) 2018 by the authors. Licensee MDPI, Basel, Switzerland. This article is an open access article distributed under the terms and conditions of the Creative Commons Attribution (CC BY) license (http://creativecommons.org/licenses/by/4.0/). 